Csiki Varga Tamás - Etl Alex:

\title{
NÉMETORSZÁG STRATÉGIAI JÖVŐKÉPE ÉS A BUNDESWEHR REFORMFOLYAMATA
}

\author{
DOI: 10.35926/HSZ.2020.1.2
}

ÖSSZEFOGLALÓ: A német stratégiai gondolkodást 2015-ben új alapokra helyezték az ún. müncheni konszenzus kialakitása által, ami a 2016-os Fehér Könyvben, majd a 2018-as Bundeswehr Koncepcióban is jól látható tartalmi elemekkel jelent meg. A szerzők tanulmányukban előbb bemutatják a német stratégiai gondolkodásban 2015 óta tapasztalt változásokat, illetve ennek jövőképét, majd értékelik a Bundeswehr helyzetét, a 2010-ben kezdett reformfolyamat eredményeit a védelmi kiadások trendjei, a személyi állomány és haditechnikai eszközök, valamint a készenléttel, modernizációval kapcsolatos problémák tükrében. Az elemzés a jelenlegi német stratégiai tervezési időszakra, 2032-ig szóló képességfejlesztési kitekintéssel zárul.

KULCSSzAvak: Németország, Bundeswehr, védelempolitika, katonai stratégia, képességfejlesztés

\section{A NÉMET STRATÉGIAI GONDOLKODÁS A „NORMALIZÁLÓDÁS" ÚTJÁN}

A 20. századi háborús tapasztalatok nyomán a német stratégiai gondolkodás hat önkorlátozó pillér körül kristályosodott ki, amelyek a következők voltak: antimilitarizmus, multilateralizmus, a nyugati integráció melletti elköteleződés, a Bundeswehr belső normakontrollja (Innere Führung) és az „,egyenruhás állampolgár” koncepciója, valamint a haderő erös demokratikus ellenőrzése (Parlamentsarmee). ${ }^{1}$ E normatív pillérek a katonai eröre mint a külpolitika eszközére csak védelmi célokra használható végső eszközként (ultima ratio) és kizárólag Németország szövetségeseivel együtt történő alkalmazás keretében tekintettek.

A nemzetközi rendszer és az európai biztonsági környezet átalakulásával az 1990es években a német külpolitika választás elé került: folytatja a korábbi, pacifizmust és multilateralizmust a középpontba helyező, reaktív gyakorlatot, vagy a vele azonos hatalommal és befolyással bíró országokhoz hasonlóan nagyobb hangsúlyt fektet az önálló nemzeti érdekérvényesítésre? ${ }^{2} \mathrm{E}$ „normalizálódás” a mai napig tartó, változó intenzitású politikai és társadalmi vitába ágyazott, sok esetben a német társadalom érdeklődésének hiányával vagy ellenérzésével küzdő elhúzódó folyamat, amelynek eredményeit a német nemzetközi és szövetségesi szerepvállalás változásával lehet leginkább mérni. A normalizálódás fö

Csiki Tamás: Miért marad továbbra is visszafogott a német védelempolitika? Nemzet és Biztonság - Biztonságpolitikai Szemle, VII. évf. 2014/5., 98.

2 Hettyey András: Különutas kezdeményezések: fordulat a német külpolitikában? Nemzet és Biztonság - Biztonságpolitikai Szemle, VIII. évf. 2015/1., 48. 
hajtóereje a bővülő és mélyülő európai integrációban játszott egyre nagyobb súlyú német gazdasági és politikai szerep - ezzel együtt pedig a szövetségesek növekvő elvárása - volt.

A szigorúan antimilitarista attitűd 1994-ig tartott, amikor a délszláv válság kapcsán megfogalmazódott nagyobb válságkezelési szerepvállalás lehetőségének tisztázása érdekében a Szövetségi Alkotmánybíróság állásfoglalásában kimondta, hogy Németország felvállalhatja a kollektív biztonsági rendszerhez tartozásából adódó és azzal együtt járó feladatokat. A német nemzetközi katonai szerepvállalás egyik normatív alapfeltétele azóta is az ENSZ BT felhatalmazása, a másik pedig, hogy olyan kollektív biztonsági szervezet keretében kerüljön rá sor, amelynek Németország tagja. ${ }^{3}$ Az 1994-es AB-határozatot követően fokozatosan - mind földrajzilag, mind müveleti mandátum tekintetében - kibővült a német nemzetközi szerepvállalás, aminek jelentős mérföldköve volt a NATO 1999-es koszovói légi háborúja.

Az ezredfordulót követően a jelentős afganisztáni szerepvállalás így akár logikus következő lépésnek is tekinthető. Még akkor is, ha mindez ismét élénk politikai és társadalmi vitát váltott ki azzal kapcsolatban, hogy Németország készen áll-e a jelentősebb nemzetközi szerepvállalásra, és e szerepvállalásnak hol találhatók a földrajzi, müveleti határai, illetve milyen szerepet hajlandó támogatni az önkorlátozó békekultúrában szocializált német társadalom. Nem véletlen, hogy Hanns W. Maull 2003-ban még amellett érvelt, hogy addig nem lehet eredményes a német külpolitika, amíg a társadalom nem képes meghaladni erős önkorlátozó hagyományait, a politika pedig nem képes kilépni a „civil hatalom” (Zivilmacht) ${ }^{4}$ kereteiből. Hasonlóképpen, a német nagyhatalmi szerepet Hans Kundnani „geoökonómiai hatalomként” (nem pedig geopolitikai szereplöként) írta le 2006-ban, ${ }^{5}$ azaz a katonai felelősségvállalás helyett a liberális gazdasági rend gazdasági előnyeit előnyben részesítő hatalomként, amely érdekeit is elsősorban puha hatalmi eszközökkel igyekszik képviselni.

Az afganisztáni müveleti részvétel azonban megteremtette a geopolitikai felelősségvállalás és az érdekek katonai eszközökkel történő védelmének narratíváját. Ez a szerepvállalás a kollektív védelmi kötelezettségek korábbi elfogadását kibővítette a kooperatív biztonsági együttműködéssel is, azaz a transzatlanti térség partnerállamainak támogatásával. (Ezt a gyakorlatot a következő évtizedben a partnerállamok biztonsági erőinek kiképzésére fókuszáló Ertüchtigung doktrínája ${ }^{6}$ egészítette ki.) Mindezek eredményeképpen a 2006-os német biztonságpolitikai Fehér Könyv ${ }^{7}$ az ezredforduló nemzetközi folyamatait figyelembe véve már a válságkezelő feladatoknak való megfelelést állította a középpontba - szigorúan multilaterális, szövetségesi keretekben.

A ,normalizálódás” folyamatát 2008-2014 között egy gazdasági kényszer szülte átmeneti időszak zavarta meg, amelyet az ismétlődő hangsúlyváltozások jellemeztek. Ez volt a kiindulópontja a Bundeswehr 2011-ben kezdődő „reformjának” (Neuausrichtung) is, amit a gyakorlatban a Wolfgang Schäuble által 2014-ig előirányzott 80 milliárd eurós államháztartási kiadáscsökkentésből a védelmi tárcára kiszabott 8,3 milliárd euró indított el. ${ }^{8}$ Átfogó

3 Markus Kaim: Die Mandatierung von Auslandeinsätzen der Bundeswehr. 26. 05. 2015. http://www.bpb.de/politik/ grundfragen/deutsche-verteidigungspolitik/204755/themengrafik-akteure (Letöltés időpontja: 2019. 08. 22.)

4 Hanns W. Maull: Auf leisen Sohlen aus der Aussenpolitik? Internationale Politik, IX. évf. 2003, 09., $19-30$.

5 Hans Kundnani: Germany as a Geo-economic Power. The Washington Quarterly, XXXIV. évf. 2011/3., 40-42. https://doi.org/10.1080/0163660X.2011.587950 (Letöltés időpontja: 2019. 08. 22.)

6 Bővebben lásd Csiki Varga Tamás: Vezetőváltás a német védelmi tárca élén. SVKK Nézőpontok, 2019/3., 2.

7 Weissbuch 2006 zur Sicherheitspolitik Deutschlands und zur Zukunft der Bundeswehr. Bundesministerium der Verteidigung, Berlin, 2016.

8 Csiki Tamás: Németország - Európa vezető hatalma, vagy kiszámíthatatlan szövetséges? Nemzet és Biztonság - Biztonságpolitikai Szemle, VI. évf. 2013/5-6., 71. 
értelemben három fö célt láthattunk a folyamat mögött: növelni kívánták a Bundeswehr nemzetközi bevethetőségét, fenntarthatóvá akarták tenni a finanszírozást, valamint alkalmazkodni akartak a változó demográfiai helyzethez (a népesség fogyásával és az erősödő munkaerőpiaci versennyel a potenciális katonák csökkenő számához).

A Neuausrichtung a haderő feladatspektrumát - az általános honvédelmi és kollektív védelmi feladatok mellett - a 2006-os Fehér Könyvvel összhangban a megnövekedett válságkezelési feladatokra koncentrálva határozta meg. Ez a sorkötelesség felfüggesztésével és a teljes mértékben professzionális haderőre való áttéréssel, valamint a párhuzamosan bejelentett közel 70 ezer fös létszámcsökkentéssel lényegében haderőmodell-váltást jelentett. ${ }^{9}$

Thomas de Maizière védelmi miniszter a haderő struktúrája és feladatspektruma tekintetében az ,inkább széles, mint mély” (,Breite vor Tiefe”) képességspektrum kialakítását tűzte ki célként. Ennek megfelelően olyan Bundeswehrt kívánt látni a reform (eredetileg) 2017-re tervezett végére, amely a sokféle müveleti forgatókönyv szerint mindenféle feladatot képes ellátni, fenntartja teljes profilját, és nem „szakosodik” egyes képességekre, mint azt Európában számos ország hadereje - kényszerüségből - a gazdasági válság hatására tette. E széles képességspektrum nemcsak a területvédelmet és a kollektív védelmet foglalja magában, hanem válságkezelő és békemüveleteket távoli térségekben, terrorizmusellenes fellépést, kutató-mentő és evakuációs feladatokat, valamint a humanitárius segítségnyújtást és a civil államépítési és fejlesztési szerepvállalás támogatását. A Bundeswehr nemzetközi ambíciószintjét ennek megfelelően a korábbi 7000 helyett 10000 föben határozták meg. ${ }^{10}$

A széles képességspektrum megtartásának „természetes” következménye volt a már bejelentett létszámcsökkentés mellett a haditechnikai eszközök számának tervezett csökkentése is. Ezt elsősorban olyan müveleti forgatókönyvekre gondolva kezdeményezték, amelyeket akkor kevésbé tartottak valószínünek: így például a nagy méretü, hagyományos erőkkel végrehajtott területvédelmi müveletekhez szükséges nehéz haditechnika tekintetében beszéltek akár 20-30\%-os leépítési tervekről is. ${ }^{11}$ Nem véletlen, hogy ennek lettek az eredményei a néhány évvel később részlegesen feltöltött alakulatok, hiányzó vagy amortizálódott haditechnikai eszközök és akadozó kiképzés, mert a túl „vékony” haderőstruktúra már nem tudta megnyugtatóan lefedni a széles képességspektrumot. (2015-re például kialakult az a gyakorlat, hogy a szárazföldi egységeket „feltöltöttnek” minősítették már akkor is, ha a haditechnikai eszközök 70\%-ával rendelkeztek - müveleti alkalmazás esetén pedig más egységektől töltötték fel a hiányokat. ${ }^{12} \mathrm{Az}$ is problémát okozott, amikor a Bundeswehrnek kellett kiállítania egy teljesen felszerelt, harckész gépesített zászlóaljat a NATO Nagyon Magas Készenlétü Összhaderőnemi Erejének szárazföldi komponenséhez 2015-ben. ${ }^{13}$ )

A széles képességspektrumban azonban az a lehetőség is benne rejlik, hogy szükség esetén (elsősorban koalíciós válságkezelő müveletekben) a Bundeswehr képes lenne integ-

${ }^{9}$ Eckpunkte für die Neuausrichtung der Bundeswehr. Nationale Interessen wahren - Internationale Verantwortung übernehmen - Sicherheit gemainsam gestalten. Bundesministerium der Verteidigung, Berlin, 2011.

${ }^{10}$ Verteidigungspolitische Richtlininen - Nationale Interessen wahren - Internationale Verantwortung übernehmen - Sicherheit gemainsam gestalten. Bundesministerium der Verteidigung, Berlin, 2011, 22.

${ }^{11}$ Csiki Tamás: A gazdasági válság hatása a Magyarországgal szövetséges államok védelmi reformjaira és stratégiai tervezésére. Nemzet és Biztonság - Biztonságpolitikai Szemle, VII. évf. 2014/2., 94.

12 Mangelverwaltung bei der Bundeswehr: neue Begriffe, gleicher Mangel. 02. 06. 2015. https://augengeradeaus. net/2015/06/mangelverwaltung-bei-der-bundeswehr-neue-begriffe-gleicher-mangel/ (Letöltés időpontja: 2019. 08. 22.)

13 Justyna Gotkowska: High on reassurance, low on deterrence - Germany's stance on strengthening NATO's eastern flank. OSW Commentary No. 217, Varsó, 2016. 
rálni a kisebb szövetséges államok haderőinek egyes elemeit. Ezt a megközelítést tükrözték a 2013-as Bundeswehr-koncepció ${ }^{14}$ nemzetközi szerepvállalásra és képességfejlesztésre vonatkozó rendelkezései is.

A nemzetközi események is alátámasztották a német kormány értékelését, mely szerint egyre több és komolyabb nemzetközi válsággal kell szembenézni. 2010-től az arab tavasz eseményei, 2011-ben a líbiai NATO-beavatkozás, 2013-ban a Közép-afrikai Köztársaság és a Mali területén fellángoló fegyveres konfliktusok, majd a szíriai polgárháború elmélyülése és az „Iszlám Állam” előretörése 2014-ben Szíriában és a szomszédos Irakban nyilvánvalóvá tették, hogy bőven adódna lehetőség a német szerepvállalásra e válságok megfékezésében. Részben a sorozatos válságok, de még inkább a 2013-2014-es ukrajnai események végül további változásokat idéztek elő a német stratégiai gondolkodásban, amelyek jelentősen eltértek a 2010-2011-ben kialakított iránytól.

Az új külpolitikai álláspont „,müncheni konszenzus” néven vált ismertté, mert a 2014es müncheni biztonságpolitikai konferencián elmondott vezetői beszédek Joachim Gauck (akkori) államelnök, Ursula von der Leyen (akkori) védelmi miniszter és Frank-Walter Steinmeier (akkori) külügyminiszter részéről egységesen és egymást erősítő jelleggel a nagyobb felelősségvállalást állították a középpontba. Gauck azt hangoztatta, hogy „,Németországnak és európai partnereinek nagyobb felelösséget kell vállalniuk saját biztonságukért”. ${ }^{15}$ Steinmeier állásfoglalása szerint a jövőben , Németországnak korábban, jelentősebb mértékben és hatásosabban kell szerepet vállalnia a kül-és biztonságpolitikában”. ${ }^{16}$ Von der Leyen pedig úgy nyilatkozott, hogy ,a szövetségi kormány felkészült arra, hogy növelje nemzetközi felelösségvállalását”. ${ }^{17}$

Ez utóbbit egy évvel később szintén Münchenben Von der Leyen úgy értelmezte a gyakorlatban, hogy Németország szövetségesei és partnerei körében központi szerepet kíván játszani és (morálisan) jó példával, (politikailag) iránymutatással, illetve (katonailag) stratégiai képességek biztosításával „,középről” képes vezetni (,,führen aus der Mitte”). ${ }^{18}$ Látva az ehhez szükséges robusztusabb katonai - elsősorban vezetés-irányítási - képességeket, illetve szembesülve a Bundeswehr folyamatos készenléti hiányosságaival, addigra meghaladottá vált a korábbi „Breite vor Tiefe” megközelítés is. ${ }^{19}$ A berlini vezetés elkezdett politikai tökét gyüjteni ahhoz, hogy a Bundeswehr újbóli megerősítését, feltöltését és modernizációját immár a legszorosabb európai szövetségesekkel összehangolva előkészítsék.

${ }_{14}$ Konzeption der Bundeswehr, 2013. Bundesministerium der Verteidigung, Berlin, 2013.

15 Deutschlands Rolle in der Welt: Anmerkungen zu Verantwortung, Normen und Bündnissen. 31. 01.2014. http://www.bundespraesident.de/SharedDocs/Reden/DE/Joachim-Gauck/Reden/2014/01/140131-MuenchnerSicherheitskonferenz.html;jsessionid=128C976C0C12F9C024A948151A0017A1.2_cid293 (Letöltés időpontja: 2019. 08. 30.)

16 Stefan Braun - Stefan Kornelius: Es wird zu Recht von uns erwartet, dass wir uns einmischen. 30. 01.2014. http://www.auswaertiges-amt.de/DE/Infoservice/Presse/Interviews/2014/140130-BM_SZ.html (Letöltés idöpontja: 2019. 08. 31.)

17 Rede der Bundesministerin der Verteidigung, Dr. Ursula von der Leyen, anlässlich der 50. Münchner Sicherheitskonferenz. https://www.securityconference.de/fileadmin/MSC_/2014/Reden/2014-01-31_Rede_ BMin_von_der_Leyen_MSC_2014.pdf (Letöltés időpontja: 2019. 08. 30.)

18 Aus der Mitte führen, gemeinsam kämpfen. 06. 02. 2014. https://www.sueddeutsche.de/politik/muenchnersicherheitskonferenz-aus-der-mitte-fuehren-gemeinsam-kaempfen-1.2339894 (Letöltés időpontja: 2019. 08. 30.)

${ }_{19}$ Bundeswehr geht neue Wege. „Breite vor Tiefe” ist Geschichte. 27. 02. 2015. https://www.n-tv.de/politik/ Breite-vor-Tiefe-ist-Geschichte-article14599116.html (Letöltés időpontja: 2019. 08. 30.) 
Két évvel később, az új - és máig hatályos - Fehér Könyv ${ }^{20}$ hivatalos kül- és biztonságpolitikai célkitűzéssé tette a nagyobb mértékủ és hitelesebb nemzetközi szerepvállalást. Fontos jelezni, hogy a müncheni konszenzus explicit módon is kilépett a civil hatalmi szerepfelfogásból, amikor nemcsak a szövetségi keretekben történő szerepvállalás katonai elemei mellett tett hitet, hanem továbblépve azt is felvetette, hogy Németország ad hoc koalíciókban is részt vehet, sőt egyoldalúan maga is kezdeményezheti a katonai erő alkalmazását válságkezelő céllal. ${ }^{21}$

A fentiekkel párhuzamosan Oroszország visszatérő érdekszféra-politikája a katonai erő alkalmazása Európán belül és a hidegháború végén kialakított európai biztonsági architektúra megváltoztatása Ukrajna területi integritásának megsértésével, a Krím illegális annexiójával és a kelet-ukrajnai fegyveres konfliktus életben tartásával a védelempolitikai gondolkodás terén is változást idézett elő Berlinben. Ahogy két évtized válságkezelés után a NATO esetében is visszatért a kollektív védelem a szövetség alapfeladatainak első helyére, Németország is változtatott a 2010-es elképzeléseken: olyan robusztus haderőstruktúra kialakítását tüzte ki célul, amely egyes szövetséges alegységeket is képes integrálni, és így közös műveleti tervezés, illetve vezetés-irányítás mellett közösen vehet részt kollektív (terület)védelmi müveletekben.

\section{A NÉMET VÉDELMI KIADÁSOK TRENDJEI ÉS A BUNDESWEHR KÉSZENLÉTE}

Nemcsak az elmúlt közel tíz év haderő-átalakítása, hanem a következő évek fejlesztési kilátásai szempontjából is meghatározó, hogy milyen erőforrásokat fordít Berlin a védelemre, és azokat mennyire eredményesen képes felhasználni. A Bundeswehr-reform kezdetét követően folyamatosan a GDP 1,15-1,3\%-a között tartották a védelmi kiadásokat; a védelmi költségvetés 2015 után indult növekedésnek, és a becslések alapján 2018-ban is csak a GDP 1,24\%-át érte el, ami nominálértéken megközelítőleg 49 milliárd dollárt (41,5 milliárd eurót) jelenthet. ${ }^{22}$ Söt, a nemrég leköszönt védelmi miniszter, Ursula von der Leyen korábbi tervei szerint a védelmi kiadások mértéke 2024-re elérhetné a GDP 1,5\%-át. ${ }^{23}$ Von der Leyen azt is hangsúlyozta, hogy a teljes védelmi költségvetésböl - annak évi 3,5-4,5 milliárd dolláros (2,9-3,8 milliárd eurós) emelésével - összesen mintegy 140 milliárd dollárt (118 milliárd eurót) fordítana eszközbeszerzésre 2030 -ig. ${ }^{24}$

Az optimista várakozásokat ugyanakkor némiképp árnyalja, hogy korábban csak jelentős közbenjárása és hivatalos tiltakozása árán sikerült elérnie, hogy a 2018 tavaszán benyújtott költségvetés-tervezetben feltüntetett 41,5 milliárd euró (49 milliárd dollár) helyett

${ }^{20}$ Weißbuch 2016 zur Sicherheitspolitik und zur Zukunft der Bundeswehr. Bundesministerium der Verteidigung, Berlin, 2016.

${ }^{21}$ Daniel Keohane: Constrained Leadership: Germany's New Defense Policy. CSS Analyses in Security Policy, No. 201, Zürich, 2016, 3.

${ }^{22}$ Defence Expenditure of NATO Countries (2011-2018). 8. 14. 03. 2019. https://www.nato.int/cps/en/natohq/ news_164482.htm (Letöltés időpontja: 2019.08.13.)

${ }^{23}$ Joshua Posaner: German defense minister strikes back on NATO spending target. 19. 04. 2019. https://www. politico.eu/article/german-defense-minister-ursula-von-der-leyen-strikes-back-on-donald-trump-nato-spendingtarget/ (Letöltés időpontja: 2019. 08. 09.)

${ }^{24}$ Christian Mölling: Germany’s Defense Budget Increase: Analytically Wrong but Politically Right. 28. 01. 2016. http://www.gmfus.org/blog/2016/01/28/germany\%E2\%80\%99s-defense-budget-increase-analytically-wrongpolitically-right (Letöltés időpontja: 2019. 08. 01.) 
végül 43,2 milliárd euróval (50,97 milliárd dollárral) gazdálkodhatott a német védelmi szektor 2019-ben. Ez körülbelül 4,5 milliárd euróval (5,3 milliárd dollárral) több, mint a 2018-as keretösszeg, ám az eset így is jól szemlélteti a német védelempolitika nehézségeit. ${ }^{25}$ Rövid távon pozitív fejlemény, hogy a 2019 júniusában elfogadott költségvetési keretszámok 44,9 milliárd eurót (52,98 milliárd dollárt) biztosítanak a védelmi szektor számára 2020-ra. ${ }^{26}$ Ehhez képest a 2019 nyarán elfogadott költségvetés alapján a védelmi kiadásokra fordítható keret 2021-re nemhogy nőne, hanem előbb 44,08 milliárd euróra (52,01 milliárd dollárra), majd 2023-ra 43,98 milliárd euróra (51,89 milliárd dollárra) csökkenne. ${ }^{27}$ Ráadásul a kismértékű nominális növelés a jelenlegi trendek alapján inkább csak a GDP arányában szinten tartásra, semmint a 2024-ig tervezett 1,5\%-os cél elérésére lenne elegendő. A védelmi kiadások alacsony szintje miatt így nem csupán Berlin áll évek óta a NATO-n belüli tehermegosztásról szóló viták középpontjában, hanem a német haderő is tartósan alulfinanszírozottá vált.

A megszorító intézkedésekből fakadó költségvetési nehézségeket tovább fokozták a strukturális hiányosságok és a rossz menedzsment, aminek köszönhetően többször is elöfordult, hogy a nyilvánvaló szükségletek ellenére sem sikerült a rendelkezésre álló forrásokat teljes egészében elkölteni (2017-ben például az eszközbeszerzésre szánt 5,9 milliárd euróból végül 600 millió maradt a kasszában). ${ }^{28} \mathrm{~A}$ folyamat eredményeképp a Bundeswehr jelentősen amortizálódott, és a szervezet készenléti és bevethetőségi szintje is csökkent.

A Bundeswehr személyi állományának csökkenését 2016-ban sikerült megállítani: létszáma jelenleg 181 ezer fö körüli, ami azonban még jelentősen elmarad a 2024-re kitüzött 198 ezer fös céltól. A 2019. júliusi hivatalos állapot alapján ugyanis mintegy 173 ezer hivatásos és további körülbelül 8 ezer önkéntes katona szolgált a haderőben. ${ }^{29}$ Valószínüsíthető, hogy a hiány mérséklése érdekében a Bundeswehr előbb vagy utóbb megnyit bizonyos pozíciókat az európai uniós állampolgárok előtt is, ezáltal tovább fokozva a szakképzett, németül (is) beszélő munkaerőért folytatott versenyt (Közép-) Európában. A cél 2024-re a 198 ezer fős haderő kialakítása. ${ }^{30}$ Bár az utóbbi években látott növekedés és a kitűzött cél is pozitív fejleménynek tekinthető, ugyanakkor a Bundeswehr feltöltöttségének nehézségeit érzékelteti, hogy - a magasabb szintü beosztásokban - rövid távon mintegy 21 ezer pozíció várt feltöltésre. ${ }^{31}$

A német védelmi költségvetés belső megoszlását tekintve illeszkedik ahhoz az általános trendhez, hogy a legnagyobb költségvetési tételt (2018-ban körülbelül 47\%-ot) a személyi kiadások jelentik, ami rendszerint az eszközbeszerzésre fordított kiadások alacsonyabb szintjét eredményezte. A német ráfordítások mértéke ugyanis látványosan alulmúlja a jelentős európai haderők eszközbeszerzésre fordított kiadásait, és 2011 óta egyszer sem közelítette meg a kitüzött 20\%-os NATO-célt. ${ }^{32}$

\footnotetext{
${ }^{25}$ Sebastian Spenger: German defense budget angers critics - including the defense minister. 02. 05. 2018. https:// www.defensenews.com/global/europe/2018/05/02/german-defense-budget-angers-critics-including-the-defenseminister/ (Letöltés időpontja: 2018. 05. 02.)

${ }^{26}$ Gesamtwirtschaftliche Ausgangslage und finanzpolitische Konzeption. Bundesfinanzministerium, Berlin, 2019.

${ }^{27}$ Unterrichtung durch die Bundesregierung. Finanzplan des Bundes 2019 bis 2023. Bundesrat, Berlin, 2019, 22.

${ }^{28}$ Tobias Buck: Germany struggles to find ways of spending extra cash on defence. https://www.ft.com/ content/43cf404c-59a4-11e8-bdb7-f6677d2e1ce8 (Letöltés időpontja: 2019. 07. 29.)

${ }^{29}$ Stärke: Militärisches Personal der Bundeswehr. Bundeswehr, Berlin, 2019.

${ }^{30}$ Unterrichtung durch den Wehrbeauftragten. Jahresbericht 2017. (59. Bericht.) Bundestag, Berlin, 2018, 20.

${ }^{31}$ Uo. 21.

${ }^{32}$ Defence Expenditure of NATO Countries (2011-2018): i. m.
} 
Bár papíron a német haderő méretei és eszközei első ránézésre impozánsnak tűnhetnek, a 2011 óta fennálló tartós alulfinanszírozottság egyértelműen érezteti hatásait. Ennek nyomán az elmúlt évek során egymást érték a Bundeswehr fegyverzetével kapcsolatos különböző botrányok. Emellett a hivatalos jelentések sem festenek túl jó képet a Bundeswehr készenlétéről: a haderő fegyverrendszereinek állapotáról készült és 2018 elején nyilvánosságra hozott jelentés (Bericht zur materiellen Einsatzbereitschaft der Hauptwaffensysteme der Bundeswehr) ${ }^{33}$ lesújtóan nyilatkozott az eszközállományról. ${ }^{34}$ Feltehetöleg ez - és a jelentés nyomán felerősödő hazai és nemzetközi kritikák - az oka annak, hogy a 2019 márciusában elkészült újabb jelentést már titkosították. ${ }^{35}$ A jelentés 2015 márciusa és 2017 decembere közötti időtávon vizsgálta a fegyverrendszerek készenlétét. Ez idő alatt összességében javult az eszközállomány állapota, ugyanakkor bizonyos kulcsfontosságú fegyverrendszerek esetében visszaesés volt tapasztalható. ${ }^{36}$

Különösen kritikusnak tekinthető a Leopard típusú harckocsik rendelkezésre állása, hiszen a 244 eszközből átlagosan 106 darab volt bevethetö (sőt a 2017. decemberi mélyponton ez a szám mindössze 70 körül alakult). ${ }^{37}$ Ez a teljes állomány mintegy 43\%-át jelentette. Ráadásul ez az arány a többi eszköz esetében sem volt feltétlenül jobb. A 202 darab Boxer páncélozott szállító harcjármü közül átlagosan 109, az 58 darab NH90 szállítóhelikopterből átlagosan 13, a 382 darab Marder páncélozott szállító harcjármüből átlagosan 212 volt bevethető a vizsgált időszakban. ${ }^{38}$ Utóbbi kapcsán ráadásul negatív tendencia tapasztalható: 2017 decemberében ugyanis a bevethető Marderek száma inkább a 170-et közelítette. Kirívó a viszonylag modern eszköznek tekinthető Puma páncélozott harcjármü esete, hiszen míg 2017 januárjában a mintegy 120 eszközből 25 volt bevethető, addig 2017 decemberére 176 eszközből körülbelül 60. Ez a trend azt jelenti, hogy lényegében több eszközzel nőtt a teljes Puma állomány, mint a bevethető állomány. ${ }^{39}$ Ezen némiképp javíthatott, hogy azóta még tovább növekedett a teljes állomány, és 2018. novemberében 248 Puma állt a haderő rendelkezésére. ${ }^{40}$ A 121 darab PZh 2000 típusú önjáró lövegből 2017 nyarán kevesebb mint 20, majd 2017 decemberében körülbelül 45 volt bevethetö. ${ }^{41}$

A haditengerészet kötelékében szolgáló 14 fregattból átlagosan 5, a 6 darab 212A típusú tengeralattjáróból pedig 2017 augusztusától 0 (!) volt bevethető, tehát a Bundeswehr lényegében elvesztette vízfelszín alatti képességét a vizsgált időintervallumban. ${ }^{42}$

A Luftwaffe Tornado és Eurofighter típusú repülőgép-állományára egyaránt igaz, hogy nagyjából 30\%-ban voltak bevethetők, míg az A400M szállítógépek esetében elmondható,

\footnotetext{
${ }^{33}$ Módszertani szempontból a 2017-es jelentés különbséget tesz a teljes eszközpark, a mintavételi eszközpark és a megfelelő készenléti szintet elérő eszközpark között. A teljes és a mintavételi eszközpark közti különbség az, hogy az előbbi magában foglalja az éppen karbantartás alatt lévő vagy az adott szervezetnél éppen nem elérhető eszközöket is. Ugyanakkor könnyü belátni, hogy ezek sem érik el a megfelelő készenléti szintet, így az elemzésünkben feltüntetett számokat is a teljes eszközállományhoz viszonyítjuk.

${ }^{34}$ Bericht zur materiellen Einsatzbereitschaft der Hauptwaffensysteme der Bundeswehr 2017. Bundesministerium der Verteidigung, Berlin, 2018.

35 Neuer Bericht zur Einsatzbereitschaft - umfangreicher und detaillierter. Bundesministerium der Verteidigung, Berlin, 2019.

${ }^{36}$ Bericht zur materiellen Einsatzbereitschaft... i. m. 8.

37 Uo. 45.

38 Uo. 48-51.

39 Uo. 53.

${ }^{40}$ Unterrichtung durch den Wehrbeauftragten. Jahresbericht 2018. (60. Bericht.) Bundestag, Berlin, $2019,41$.

${ }^{41}$ Bericht zur materiellen Einsatzbereitschaft... i. m. 59.

${ }^{42}$ Uo. $66-68$.
} 
hogy míg a teljes eszközpark 8-ról 14 gépre növekedett, addig a bevethető gépek száma folyamatosan csak 3 darab volt. ${ }^{43}$

Összességében a készenléttel kapcsolatos kihívások nyomán a Bundeswehr az elmúlt években rendkívül túlterheltté vált. 2011-től a megszorítások jegyében egyre nagyobb mértékü lett a Bundeswehr eszközhiánya, amit eddig csak különböző kényszermegoldásokkal (például egyik alakulattól a másikhoz csoportosítással) tudtak ideiglenesen áthidalni, elfedni. ${ }^{44}$ Annak érdekében, hogy a haderő müveleti szerepvállalásait biztosítani tudják, gyakran elöfordult, hogy a hazai alakulatoknál csak a leamortizálódott, használhatatlan eszközök maradtak. ${ }^{45}$ Mindez pedig - bár biztosítja a müveleti feladatok ellátását - hosszú távú problémákat okoz, hiszen akadályozza a folyamatos kiképzést. ${ }^{46}$

\section{A BUNDESWEHR FEJLESZTÉSÉNEK JÖVŐKÉPE}

2017-ben a megváltozott kül-, biztonság- és védelempolitikai célokhoz a Bundeswehr hosszú távú (2032-ig szóló) fejlesztését is hozzáigazították. A tervezést Erhard Bühler, a Bundeswehr tervezési részlegének vezetője készítette elö, akinek két vonatkozó dokumentumát - „Aktuelle Planungen in der Bundeswehr”, illetve „,Vorgabe für die Fähigkeitsprofil der Bundeswehr” (általánosan csak „Bühler Papiere”) - a Frankfurter Allgemeine Zeitung szivárogtatta ki 2017 márciusában. ${ }^{47}$ Ezek fektették le az alapjait a haderő feladatait és általános fejlesztési irányelveit meghatározó, 2018-ban elfogadott új Bundeswehr-koncepciónak (Konzeption der Bundeswehr), ${ }^{48}$ illetve az ez alapján kialakított, a Bundeswehr képességfejlesztési terveit a következő 15 évre meghatározó (egyébként titkosított) tervdokumentumnak (,,Fähigkeitsprofil der Bundeswehr") is.

A tervezés alapját az a meggyőződés jelentette, hogy a 2011-es Neuausrichtung által szabott elképzelésektől el kell szakadni, mivel a Bundeswehr jelentős mennyiségi és részben minőségi képességvesztést szenvedett el, ami a megváltozott biztonsági környezetben nem fogadható el. Már nem a 2006-os Fehér Könyvben rögzített konfliktusmegelőzési és válságkezelö müveletek katonai képességigényeihez kell szabni a Bundeswehr haderőstruktúráját és haditechnikai felszereltségét, hanem a 2016-os, a szövetségi kollektív védelmet és a nemzeti területvédelmet középpontba állító Fehér Könyv ambíciószintjét és feladatszabását kell ahhoz alapul venni. Az újonnan megerősített Bundeswehrnek emellett olyan új képességekkel is rendelkeznie kell, amelyek képesek biztosítani az eredményes kiberhadviselést, a hibrid müveletekben való részvételt és az ezek elleni fellépést, a müveleti súlypontot gyorsan áthelyezni képes mobil haderőelemeket, valamint a szövetséges haderők közvetlen támogatását, egyes alegységek integrálását is. A Bundeswehrrel szemben alapvető elvárássá vált a magasabb szintü bevethetőség, harckészség és rendelkezésre állás, a vezetés-irányítási struktúrák ellenálló képessége, minden egység esetében a nagyobb fokú multifunkcionalitás, nem utolsósorban pedig a tartalékos állomány szorosabb integrációja minden fegyvernem esetében.

\footnotetext{
${ }^{43}$ Uo. 86-94.

${ }^{44}$ Rainer L. Glatz - Martin Zapfe: Ambitious framework nation: Germany in NATO. SWP Comments $2017,2$.

${ }^{45}$ Unterrichtung durch den Wehrbeauftragten. Jahresbericht 2017, 42-43., és Unterrichtung durch den Wehrbeauftragten. Jahresbericht 2018, 42.

46 Uo.

47 Langfrist-Planung: Bundeswehr mit mehr Fähigkeiten zur Bündnisverteidigung (m. Transkript). 19. 04. 2017. https://augengeradeaus.net/2017/04/langfrist-planung-bundeswehr-mit-mehr-faehigkeiten-zurbuendnisverteidigung/ (Letöltés időpontja: 2019. 08. 31.)

${ }^{48}$ Konzeption der Bundeswehr, 2018. Bundesministerium der Verteidigung, Berlin, 2018.
} 
A Bühler Papiere első része amellett is egyértelmúen állást foglalt, hogy a Bundeswehrnek a nemzetitől a (NATO) szövetségi felé kell eltolnia tervezési elképzeléseit, a kialakítandó cselekvési potenciált és teljesítményt, nemkülönben a szövetségeseknek biztosítandó „,szolgáltatásokat" (úgymint vezetés-irányítás és más stratégiai képességek) is ezzel a mércével kell mérni. ${ }^{49}$ A 2032-ig szóló haderőtervezés egyik kulcsszava a „többnemzetiség” - mégpedig, mint látni fogjuk, konkrétan más nemzetek egyes haderőelemeinek és a német haderő egyes alegységeinek kölcsönös integrációjával, közös strukturális elemekben. Erre a 2013-ban Berlin által kidolgozott, majd a NATO által felkarolt keretnemzet-koncepció (Framework Nation Concept - FNC) biztosít lehetőséget. A német stratégiai gondolkodás fent vázolt nagyobb felelősségvállalási szándéka a gyakorlatban úgy jelenik meg, hogy a Bundeswehr a kisebb nemzetek haderőelemeit a képességek szintjén integrálja, például kollektív védelmi müveletekben: a Bundeswehr vezetés-irányítási rendszere, struktúrái „,anyahajóként dokkolják" más haderők alegységeit. ${ }^{50}$

A 2018-as Bundeswehr-koncepció igyekszik a kezdetektől reálisan kezelni azt a helyzetet, hogy a haderőnek azonos erőkkel (single set of forces) is meg kell tudnia oldani a honvédelemmel és a szövetségesi kötelezettségböl eredő kollektív védelemmel, valamint az ad hoc válsághelyzetekkel kapcsolatos feladatokat. A Bundeswehr alapfeladatait (Grundaufstellung) müveleti forgatókönyvek (Missionspakete) egészítik ki. ${ }^{51}$ A fegyveres eröknek minden esetben biztosítaniuk kell a gyors, rugalmas reagálási és erőkivetítési képességet, a nemzeti és a szövetségi védelmi müveletekhez szükséges képességeket, beleértve a támogatóerők befogadását, a nemzeti válságkezelést és a kibertér védelmét szolgáló képességeket, valamint a belföldi feladatokhoz kapcsolódó képességeket. Kiegészítő jelleggel készen kell állniuk a nemzetközi válságkezelésre, az ENSZ Alapokmány VI. és VII. fejezete alapján indított békemüveletekben történő részvételre, katasztrófavédelmi feladatok ellátására, a nemzetközi partnerekkel kétés többoldalú együttmüködésekre, így például kiképzési és mentorálási, képességfejlesztési feladatokra (Ertüchtigung), illetve humanitárius müveletekre is. ${ }^{52}$

A képességfejlesztési tervdokumentumról (,Fähigkeitsprofil der Bundeswehr”) nyilvánosságra hozott információk szerint 2032-re a Bundeswehrnek 3 szárazföldi hadosztállyal, 3 légi harccsoporttal, 25 bevethető felszíni hadihajóval és 8 tengeralattjáróval, valamint egy kiber/információs műveleti csoporttal, illetve az ezeket kiegészítő, támogató ür-, különleges müveleti és kiszolgáló-támogató (logisztika, ABV-védelem, müszaki stb.) képességekkel

49 Erhard Bühler: Aktuelle Planung in der Bundeswehr: Anspruch und Ambition. 16. 03. 2017. https://www.dbwv. de/aktuelle-themen/blickpunkt/beitrag/news/aktuelle-planung-in-der-bundeswehr-anspruch-und-ambition/ (Letöltés időpontja: 2019. 08. 31.)

50 A NATO-n belül három keretnemzeti (FNC) csoport jött létre különböző feladatokkal: a német vezetésű országcsoport a közös képességfejlesztésre koncentrál, a brit vezetésű a közös expedíciós képességekre (válságkezelésre), míg az olasz vezetésű a stabilizációs szerepvállaláshoz szükséges képességekre. A német FNC-csoport két pilléren nyugszik: egyrészt 16 képességcsomag (klaszter) közös fejlesztésén (egy ilyen például a tengeralattjáró elleni hadviselés), másrészt a részt vevő államok olyan összehangolt védelmi tervezési együttműködésén, amely az „összeurópai” védelem egyes müveleti forgatókönyveinek esetére (például területvédelem) lehetővé tenné, hogy miközben a Bundeswehr biztosítja a „keretet”, a müveletek vezetés-irányítását és számos stratégiai képességet, a kisebb szövetséges államok haderőelemei „,rácsatlakoznak” erre a magstruktúrára, és közösen képesek végrehajtani műveleteket. (Erre utaltunk korábban a német stratégiai elképzelések magyarázatánál is.) Bővebben lásd Rainer L. Glatz - Martin Zapfe: NATO’s Framework Nations Concept. CSS Analyses in Security Policy, No. 218, Zürich, 2017, 12., 2.

${ }^{51}$ Die Konzeption der Bundeswehr. Ausgewählte Grundlinien der Gesamtkonzeption. Bundesministerium der Verteidigung, Berlin, 2018, 13.

52 Uo. 19. 
kell rendelkeznie. ${ }^{53}$ Első lépésként 2019-2023 között stabilizálnia kell a NATO-n belül a baltikumi szerepvállalását és biztosítania egy VJTF-dandárerő keretnemzeti feladatainak ellátását, sőt további feladatokat vállalnia haditengerészeti, légi- és különleges erőkkel. 2027-ig kell megteremteni a haderőnemek és támogatóelemek közötti, az összhaderőnemi együttmüködés jellemzőit mutató rendszerszintű hálózatos kapcsolatot (Systemverbünde); majd 2032-ig kell elérnie azt az állapotot, hogy a müveleti forgatókönyvek kiegészítő feladatait is el tudja látni.

E célok eléréséhez a szárazföldi erőket jelentősen átstrukturálják: 3 teljesen felöltött hadosztályt hoznak létre minimum 8 , maximum 10 dandárral, amelyeknek 3 hónapon belül bevethetöknek kell lenniük. Az első hadosztálynak 2026-ra kell elérnie a teljes múveleti készenlétet, amikor három, teljesen feltöltött páncélosdandár lenne bevethető 20 ezer fővel. Ezt 2031-ig követné a következő kettő. ${ }^{54}$ Jelenleg 7 szárazföldi dandár és a közös francianémet dandár áll hadrendben, ezeket az elemeket egészíthetik ki a holland 43. gépesített és a 11. légimozgékonyságú dandár, amelyeket már jelentős mértékben integráltak a német haderőstruktúrába, valamint további kelet- és közép-európai szövetségesek alegységei. A két holland dandár a német 1. páncéloshadosztályba (Oldenburg) integrálódna, kiegészítve a 9. és a 21. páncélosdandárokat. Ez a hadosztály jelentheti a NATO azonnali reagálású (VJTF) eröinek szárazföldi komponensét.

Dél-Németországban a 10. páncéloshadosztály (Veitshöchheim) 12. páncélosdandárja, 37. gépesített gyalogosdandárja és 23. hegyigyalogos-dandárja mellé integrálnak egy negyedik - várhatóan cseh - dandárt. Ezek az erők a 2032-ig tartó tervezési időszak második felében érhetik el a teljes müveleti készenlétet, három hónapos készenléti időszakkal.

A harmadik hadosztály sorsa bizonytalanabb: a légimozgékonyságú dandár (31. és 26. ejtőernyősezred) mellett egy új gépesített dandárnak (két gépesített zászlóalj, egy harckocsizászlóalj, egy tüzérosztály, müszaki és felderítőalegységek) és egy esetleges - a francia-német dandár alkotóelemeit is felhasználó - könnyüfegyverzetü, gyorsreagálású erőnek a kialakítása is felmerült szakmai körökben. Ebben a felállásban azonban a harmadik hadosztály képességei nem lennének összehasonlíthatók a másik két nehézhadosztállyal. Láthatóan maradna feltöltendő hely a szövetségesek alegységei számára is.

Olyan információ is napvilágot látott, hogy az Összhaderőnemi Parancsnokság eddigi 6 logisztikai zászlóalja helyett 19-et (!) alakítanának ki, ami (ha megvalósul) egyértelmüen azt a szándékot mutatja, hogy a Bundeswehr ne csupán integrálni tudjon 3-4 dandárt a szövetségesek haderöiböl, hanem képes legyen támogatást biztosítani a Közép- és a KeletEurópában szükség esetén felvonuló NATO-erőknek is. ${ }^{55}$ Mivel a haderőfejlesztési tervek továbbra is minősített dokumentumok, a kiszivárogtatott és kikövetkeztetett elemekből némi bizonytalansággal tudunk becslést alkotni arra vonatkozóan, hogy milyen mértékü létszámnövelésre lenne szükség a struktúra „robusztussá tételéhez”. Az biztosnak tűnik, hogy összességében már a felvázolt szárazföldi erő is meghaladná az Erhard Bühler által jelzett 27 zászlóaljat, ami a jelenlegihez képest legalább 15 ezer fő további - aktív vagy

\footnotetext{
53 Neues Fähigkeitsprofil komplettiert Konzept zur Modernisiering der Bundeswehr. 04. 09. 2018. https://www. bmvg.de/de/aktuelles/neues-faehigkeitsprofil-der-bundeswehr-27550 (Letöltés időpontja: 2019. 08. 31.)

${ }^{54}$ Bundeswehr-Pläne: Heer soll drei volle Divisionen bekommen. 19. 04. 2017. https://www.dbwv.de/aktuellethemen/politik-verband/beitrag/news/bundeswehr-plaene-heer-soll-drei-volle-divisionen-bekommen/ (Letöltés időpontja: 2019. 08. 31.)

55 Jürgen Dreifke: Einsatzstruktur für die Bündnisverteidigung - Bundeswehrplanung 2032. https://bw-duelmen. de/data/documents/bw-neu-txt.pdf (Letöltés időpontja: 2019. 08. 31.)
} 
tartalékos - katonát jelentene. Az eszközigényre pedig jelen ismereteink alapján még becslést sem tudunk kialakítani. ${ }^{56}$

A légierőnek a következő 15 évben el kell érnie azt a készenléti szintet, hogy naponta 350 felderítö- és harci bevetést tudjon vezetni - aminek háromnegyedét a Luftwaffe repülőgépei hajtanak végre. Képesnek kell lennie a légi uralom biztosítására Németország felett, a szövetségesekkel együttmüködve pedig meg kell tudnia szerezni a légtér ellenőrzését hadműveleti területen is. Ehhez az eszközparkot is bővíteni, illetve modernizálni kell: lecserélik a Tornado típusú harci repülögépeket és a CH-53 Sea Stallion nehéz szállítóhelikoptereket, a C-130 és az A400M szállító repülőgépeket, valamint új szállítóhelikoptereket és drónokat szereznek be. Már rövid távú célkitüzés, hogy 2021-től a Luftwaffe biztosítani tudja a szárazföldi erök csapatlégvédelmét is. ${ }^{57}$

A haditengerészetnek egyidejüleg minimum 15 felszíni hajót kell majd készenlétben tartania, amihez a következő években hat ellátóhajót, négy fregattot és az aknaszedő flottát is le kell cserélni. Új (tulajdonképpen az 1990-es évek leépítése után visszatérő) feladatként jelenik meg a levegőből végrehajtott csapásmérés, ${ }^{58}$ amihez - eddig nem tisztázott típusú vadászbombázókat is be kellene szerezni.

\section{KÖVETKEZTETÉSEK}

A 2010-ben elkezdett Bundeswehr-reform 2014-ig a válságkezelő nemzetközi szerepvállalást helyezte a középpontba az országvédelem és a kollektív védelem mellett, amihez széles képességspektrumot, de „vékony” haderőstruktúrát kívántak megőrizni a sokszínü feladatok ellátása érdekében. A sorozatos válságok Európa perifériáján és szomszédságában, különösképpen az orosz-ukrán válság 2014 után azonban eltérítették az eredeti reformirányt, és robusztus képességeket, keretnemzeti feladatokat is biztosítani tudó haderőstruktúrát követeltek meg.

A 2032-ig szóló stratégiai tervezési időszakban a Bundeswehrnek jelentős képességfejlesztésen kell átesnie mind az élőerö és a szervezet, mind a haditechnikai eszközök tekintetében. Többek között képessé kell válnia arra, hogy szükség esetén keretnemzetként három (de még inkább több) dandárerőt tudjon integrálni szövetségesei fegyveres erőiből.

Annak érdekében, hogy a Bundeswehr rövid és középtávon képes legyen megalapozni e célkitűzéseket, három, 2010 után igen kedvezőtlenül alakuló trendet kell „megfordítania”: a haditechnikait (Trendwende „Material”), a pénzügyit (Trendwende „Finanzen”) és a személyügyit (Trendwende „Personal”). Robusztusabb haderőstruktúra, bevethetö eszközök és elegendő katona nélkül ugyanis sem a nemzeti, sem a nemzetközi feladatokat nem fogják tudni megvalósítani.

Ezzel párhuzamosan a német stratégiai gondolkodás is továbblépett a „normalizálódás" útján, felkészülve arra, hogy Berlin gazdasági és politikai erejéhez mérhető katonai szerepet játsszon Európa biztonságának fenntartásában is. A „müncheni konszenzus” azonban nem szükségszerủen egyirányú folyamat, hanem egy trend irányát jelzi. E trendet történelmi (önkorlátozás), jogi-intézményi (az Alkotmány rendelkezései és a Parlament erős

\footnotetext{
56 Jelzésértékkel egy példát kiragadva: nagymértékben erősíteni kellene a tüzérséget, mivel a területvédelmi forgatókönyv (vagy akár ennek előzményeként a hagyományos erőkkel történő elrettentés) ezt megköveteli; amit úgy oldhatnak meg, hogy minden dandárhoz felállítanak egy újabb tüzérosztályt, és a hadosztályok is kapnak önálló tüzérséget.

57 Bundeswehr-Pläne: Heer soll drei volle Divisionen bekommen: i. m.

${ }^{58}$ Uo.
} 
felhatalmazása a katonai erő alkalmazásával kapcsolatban), politikai (a CDU-CSU-SPDkoalíció fennmaradásának kérdései), társadalmi (a nemzetközi szerepvállalást visszafogottan támogató, a katonait inkább ellenző közvélemény) és katonai „fékek” (készenléti, bevethetőségi problémák, elégtelen beszerzési mechanizmusok, bizonytalan védelmi költségvetés) is eltéríthetik.

\section{FELHASZNÁLT IRODALOM}

Aus der Mitte führen, gemeinsam kämpfen. 06. 02. 2014. https://www.sueddeutsche.de/politik/ muenchner-sicherheitskonferenz-aus-der-mitte-fuehren-gemeinsam-kaempfen-1.2339894

Bericht zur materiellen Einsatzbereitschaft der Hauptwaffensysteme der Bundeswehr 2017. Bundesministerium der Verteidigung, Berlin, 2018.

Braun, Stefan - Kornelius, Stefan: Es wird zu Recht von uns erwartet, dass wir uns einmischen. 30. 01. 2014. http://www.auswaertiges-amt.de/DE/Infoservice/Presse/Interviews/2014/140130-BM_SZ.html

Buck, Tobias: Germany struggles to find ways of spending extra cash on defence. https://www.ft.com/ content/43cf404c-59a4-11e8-bdb7-f6677d2elce8

Bundeswehr geht neue Wege. „Breite vor Tiefe” ist Geschichte. 27. 02. 2015. https://www.n-tv.de/ politik/Breite-vor-Tiefe-ist-Geschichte-article14599116.html

Bundeswehr-Pläne: Heer soll drei volle Divisionen bekommen. 19. 04. 2017. https://www.dbwv.de/ aktuelle-themen/politik-verband/beitrag/news/bundeswehr-plaene-heer-soll-drei-volle-divisionenbekommen/

Bühler, Erhard: Aktuelle Planung in der Bundeswehr: Anspruch und Ambition. 16. 03. 2017. https:// www.dbwv.de/aktuelle-themen/blickpunkt/beitrag/news/aktuelle-planung-in-der-bundeswehranspruch-und-ambition/

Csiki Tamás: A gazdasági válság hatása a Magyarországgal szövetséges államok védelmi reformjaira és stratégiai tervezésére. Nemzet és Biztonság - Biztonságpolitikai Szemle, VII. évf. 2014/2.

Csiki Tamás: Miért marad továbbra is visszafogott a német védelempolitika? Nemzet és Biztonság Biztonságpolitikai Szemle, VII. évf. 2014/5.

Csiki Tamás: Németország - Európa vezetö hatalma, vagy kiszámíthatatlan szövetséges? Nemzet és Biztonság - Biztonságpolitikai Szemle, VI. évf. 2013/5-6.

Csiki Varga Tamás: Vezetőváltás a német védelmi tárca élén. SVKK Nézőpontok, 2019/3.

Defence Expenditure of NATO Countries (2011-2018). 14. 03. 2019. https://www.nato.int/cps/en/ natohq/news_164482.htm

Deutschlands Rolle in der Welt: Anmerkungen zu Verantwortung, Normen und Bündnissen. 31. 01. 2014. http:/www.bundespraesident.de/SharedDocs/Reden/DE/Joachim-Gauck/Reden/2014/01/140131Muenchner-Sicherheitskonferenz.html;jsessionid=128C976C0C12F9C024A948151A0017A1.2_cid293

Die Konzeption der Bundeswehr. Ausgewählte Grundlinien der Gesamtkonzeption. Bundesministerium der Verteidigung, Berlin, 2018.

Dreifke, Jürgen: Einsatzstruktur für die Bündnisverteidigung - Bundeswehrplanung 2032. https:// bw-duelmen.de/data/documents/bw-neu-txt.pdf

Eckpunkte für die Neuausrichtung der Bundeswehr. Nationale Interessen wahren - Internationale Verantwortung übernehmen - Sicherheit gemainsam gestalten. Bundesministerium der Verteidigung, Berlin, 2011.

Gesamtwirtschaftliche Ausgangslage und finanzpolitische Konzeption. Bundesfinanzministerium, Berlin, 2019.

Glatz, Rainer L. - Zapfe, Martin: Ambitious framework nation: Germany in NATO. SWP Comments 2017. 
Glatz, Rainer L. - Zapfe, Martin: NATO's Framework Nations Concept. CSS Analyses in Security Policy, No. 218, Zürich, 2017.

Gotkowska, Justyna: High on reassurance, low on deterrence - Germany's stance on strengthening NATO's eastern flank. OSW Commentary No. 217, Varsó, 2016.

Hettyey András: Különutas kezdeményezések: fordulat a német külpolitikában? Nemzet és Biztonság - Biztonságpolitikai Szemle, VIII. évf. 2015/1.

Kaim, Markus: Die Mandatierung von Auslandeinsätzen der Bundeswehr. 26. 05. 2015. http://www. bpb.de/politik/grundfragen/deutsche-verteidigungspolitik/204755/themengrafik-akteure

Keohane, Daniel: Constrained Leadership: Germany's New Defense Policy. CSS Analyses in Security Policy, No. 201, Zürich, 2016.

Konzeption der Bundeswehr, 2013. Bundesministerium der Verteidigung, Berlin, 2013.

Konzeption der Bundeswehr, 2018. Bundesministerium der Verteidigung, Berlin, 2018.

Kundnani, Hans: Germany as a Geo-economic Power. The Washington Quarterly, XXXIV. évf. 2011/3.

Langfrist-Planung: Bundeswehr mit mehr Fähigkeiten zur Bündnisverteidigung (m. Transkript). 19. 04. 2017. https://augengeradeaus.net/2017/04/langfrist-planung-bundeswehr-mit-mehr-faehigkeitenzur-buendnisverteidigung/

Mangelverwaltung bei der Bundeswehr: neue Begriffe, gleicher Mangel. 02. 06. 2015. https:// augengeradeaus.net/2015/06/mangelverwaltung-bei-der-bundeswehr-neue-begriffe-gleichermangel/

Maull, Hanns W.: Auf leisen Sohlen aus der Aussenpolitik? Internationale Politik, IX. évf. 2003.

Mölling, Christian: Germany's Defense Budget Increase: Analytically Wrong but Politically Right. 28. 01. 2016. http://www.gmfus.org/blog/2016/01/28/germany $\%$ E2\%80\%99s-defense-budgetincrease-analytically-wrong-politically-right

Neuer Bericht zur Einsatzbereitschaft - umfangreicher und detaillierter. Bundesministerium der Verteidigung, Berlin, 2019.

Neues Fähigkeitsprofil komplettiert Konzept zur Modernisiering der Bundeswehr. 04. 09. 2018. https:// www.bmvg.de/de/aktuelles/neues-faehigkeitsprofil-der-bundeswehr-27550

Posaner, Joshua: German defense minister strikes back on NATO spending target. 19. 04. 2019. https:// www.politico.eu/article/german-defense-minister-ursula-von-der-leyen-strikes-back-on-donaldtrump-nato-spending-target/

Rede der Bundesministerin der Verteidigung, Dr. Ursula von der Leyen, anlässlich der 50. Münchner Sicherheitskonferenz. https://www.securityconference.de/fileadmin/MSC_/2014/ Reden/2014-01-31_Rede_BMin_von_der_Leyen_MSC_2014.pdf

Spenger, Sebastian: German defense budget angers critics - including the defense minister. 02. 05. 2018. https://www.defensenews.com/global/europe/2018/05/02/german-defense-budget-angerscritics-including-the-defense-minister/

Stärke: Militärisches Personal der Bundeswehr. Bundeswehr, Berlin, 2019.

Unterrichtung durch den Wehrbeauftragten. Jahresbericht 2017. (59. Bericht.) Bundestag, Berlin, 2018.

Unterrichtung durch den Wehrbeauftragten. Jahresbericht 2018. (60. Bericht.) Bundestag, Berlin, 2019.

Unterrichtung durch die Bundesregierung. Finanzplan des Bundes 2019 bis 2023. Bundesrat, Berlin, 2019, 22.

Verteidigungspolitische Richtlininen. Nationale Interessen wahren - Internationale Verantwortung übernehmen - Sicherheit gemainsam gestalten. Bundesministerium der Verteidigung, Berlin, 2011.

Weissbuch 2006 zur Sicherheitspolitik Deutschlands und zur Zukunft der Bundeswehr. Bundesministerium der Verteidigung, Berlin, 2016.

Weißbuch 2016 zur Sicherheitspolitik und zur Zukunft der Bundeswehr. Bundesministerium der Verteidigung, Berlin, 2016. 